\title{
JURNAL BIOEDUKATIKA
}

http://journal.uad.ac.id/index.php/BIOEDUKATIKA 2338-6630 (Print) | 2541-5646 (Online)

\section{Pengembangan modul discovery learning struktur tumbuhan dengan memanfaatkan potensi lokal umbul tlatar untuk meningkatkan regulasi diri dan sikap kepedulian lingkungan siswa SMA}

\author{
Dwi Hartanti ${ }^{1,}{ }^{*}$, Sajidan $^{2}$, Baskoro Adi Prayitno ${ }^{3}$ \\ Pendidikan Biologi, Fakultas Keguruan dan Ilmu Pendidikan, Universitas Sebelas Maret, Indonesia \\ ${ }^{1}$ dwi.hartanti5272@gmail.com *, 2 sajidan@fkip.uns.ac.id, ${ }^{3}$ baskoro_ap@uns.ac.id \\ * Korespondensi penulis
}

\begin{tabular}{|c|c|}
\hline \multicolumn{2}{|c|}{ Informasi artikel } \\
\hline Riwayat artike & \\
\hline Diterima & 12 Februari 2019 \\
\hline Revisi & 28 Maret 2019 \\
\hline Dipublikasikan & 10 Juni 2019 \\
\hline
\end{tabular}

Kata kunci:

Modul discovery learning

Regulasi diri

Sikap kepedulian lingkungan
Pemanfaatan potensi lokal merupakan salah satu alternatif yang dapat digunakan untuk membantu siswa mempelajari materi biologi. Penggunaan modul discovery learning dengan menggunakan potensi lokal Umbul Tlatar diharapkan dapat mempermudah pemahaman siswa terutama pada materi struktur tumbuhan. Tujuan penelitian ini yaitu untuk: 1) mengetahui karakteristik; 2) kelayakan; dan 3) efektivitas modul discovery learning terhadap keterampilan regulasi diri dan sikap kepedulian lingkungan siswa. Metode penelitian menggunakan model penelitian dan pengembangan Borg \& Gall yang dimodifikasi yaitu: 1) penelitian pendahuluan dan pengumpulan informasi 2) perencanaan 3) pengembangan desain produk awal 4) uji coba kelompok kecil 5) revisi produk utama 6) uji lapangan terbatas 7) revisi produk akhir. Instrumen yang digunakan meliputi: angket, observasi, wawancara dan tes. Data yang diperoleh yaitu data hasil validasi ahli, validasi praktisi pendidikan. Hasil uji coba dianalisis secara deskriptif kuantitatif. Hasil penelitian dan pengembangan menunjukkan 1) karakteristik modul dikembangkan berdasarkan sintak discovery learning meliputi: stimulation, problem statement, data collection, data processing, verification dan generalization, 2) Modul dinyatakan layak oleh ahli materi, ahli penyajian modul, ahli perangkat pembelajaran. Modul dinyatakan layak oleh guru dan siswa, 3) Hasil uji operasional terkait regulasi diri menunjukkan signifikansi $0,00<0,05$ dan hasil uji operasional terkait kepedulian lingkungan menunjukkan signifikansi $0,00<0,05$, disimpulkan modul discovery learning dengan potensi lokal Umbul Tlatar bermanfaat secara efektif dapat meningkatkan regulasi diri dan sikap kepedulian lingkungan siswa SMA.

\section{ABSTRACT}

Keyword:

Development of Discovery Learning Module Plant Structures by Using Potential of Umbul Tlatar Area To Enhance Self Regulation Capability and Awarness Toward Environment Attitude of High School Students. Utilization of local potential is an alternative that can be used to help students learn biological material. The use of 
the discovery learning module by using the potential of umbul Tlatar area is expected to facilitate students' understanding, especially in plant structure materials. The purpose of this research is to: 1) knowing the characteristics; 2) the feasibility; and 3) the effectiveness of the discovery learning module on the ability of self regulation and the awarness toward environment of students. The research method uses a modified Borg \& Gall research and development model, namely: 1) preliminary research and information gathering 2) planning 3) initial product design development 4) small group trials 5) main product revisions 6) limited field tests 7) product revisions. The instruments that used include: questionnaires, observation, interviews and tests. The data obtained are the results of expert validation data, validation of education practitioners, and the results of the trial were analyzed quantitatively descriptively. The results of research and development show 1) module characteristics developed based on discovery learning syntax include: stimulation, problem statement, data collection, data processing, verification, and generalization 2) the module is feasible declared by material experts, module presentation experts, learning device experts. The module is declared appropriate by teachers and students 3) the operational test results related to self-regulation show a significance $0.00<0.05$ and the results of operational tests related to environmental care show a significance $0.00<0.05$, it can be concluded that the discovery learning module by using the local potential of useful umbul Tlatar effectively in improving self-regulation and environmental care attitudes of high school students.

This is an open access article under the CC-BY-SA license.

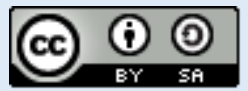

\section{Pendahuluan}

\section{Dunia pendidikan memerlukan pengajaran yang dapat meningkatkan kemampuan siswa untuk siap menghadapi tantangan global, era revolusi industri 4.0 yaitu suatu pembelajaran yang dapat menghantarkan siswa untuk memiliki keterampilan berpikir dan memecahkan} masalah.

Regulasi diri merupakan keterampilan mengontrol perilaku sendiri dan penggerak utama kepribadian manusia saat pengamatan, penilaian dan respons diri (Wenning-Vieyra, 2008). Keterampilan regulasi diri pada seseorang akan memudahkan menemukan gambar masa depannya (Taylor, Peplau, \& Sears, 2006). Regulasi diri terdapat dalam setiap individual tetapi tidak semua individu dapat memanfaatkan hal tersebut pada situasi yang tepat. Keterampilan regulasi diri perlu dilatih sehingga dibiasakan dapat menentukan pilihan- pilihan dalam hidup. Siswa harus dapat melakukan perencanaan yang tepat, yang terkait dengan pengaturan diri (self regulated) dalam mendukung tahapan proses berpikir kritis dalam pembelajarannya.

SMAN 2 Boyolali di Kabupaten Boyolali merupakan sekolah menuju adiwayata, sehingga sudah selayaknya siswa memiliki sikap kepedulian lingkungan yang baik. Hasil pengukuran sikap kepedulian lingkungan sebelum pembelajaran struktur tumbuhan diperoleh rata-rata aspek peduli terhadap keadaan lingkungan 53.29, aspek tidak merusak lingkungan 44.23, aspek menjaga kebersihan 43.14, aspek tanggung jawab terhadap lingkungan 51.54, dan aspek menjaga kenyamanan lingkungan 48.07. Berdasarkan hasil observasi dan angket penelitian sikap kepedulian lingkungan masih dalam kategori kurang.

Hasil UN 2013/2014 untuk SMAN 2 Boyolali pada kompetensi dasar 
menjelaskan sifat, ciri-ciri dan fungsi jaringan pada tumbuhan dan hewan nilai ketuntasan tingkat sekolah dengan nilai rata-rata 63.75 , tingkat kabupaten 62.89 , tingkat provinsi 65.30 dan tingkat nasional 61.51. Hasil dari ulangan harian materi Jaringan Tumbuhan masih ada 40\% siswa yang belum memenuhi KKM .

Penerapan model pembelajaran discovery learning dirasa sesuai untuk karakteristik materi struktur tumbuhan. discovery learning merupakan model pembelajaran yang lebih menekankan pada pengalaman langsung. Fokus pembelajaran tidak pada aplikasi untuk mencari pengetahuan, tetapi lebih pada membangun pengetahuan siswa melalui pengalaman, sehingga penemuan belajar menggunakan refleksi sebagai kunci untuk memahami. Sari (2014) berpendapat bahwa psikomotor terkait dengan perkembangan kemampuan otot mulai dari pergerakan refleks sederhana sampai pada resesi dan kreativitas dalam penampilan keahlian (skill). Pembelajaran perlu mendorong kreativitas dan skill pada siswa, sehingga perlu didukung dengan bahan ajar yang digunakan.

Bahan ajar merupakan faktor pendukung yang dapat mempengaruhi keberhasilan pembelajaran. Berdasarkan hasil observasi, bahan ajar belum mencantumkan aspek-aspek yang dapat melatih keterampilan regulasi diri dan sikap peduli lingkungan. Berdasarkan analisis angket kebutuhan siswa diperoleh informasi bahwa bahan ajar yang digunakan tidak menarik karena tidak berwarna, komposisi materi kurang lengkap sehingga harus mencari dari sumber lain, dan sulit dipahami. Bahan ajar yang dipakai belum memanfaatkan potensi lokal (umbul Tlatar) Boyolali. Hasil penelitian Amini \& Munandar (2010), pendidikan lingkungan berpengaruh positif saat pembelajaran berbasis outdoor. Modul dengan memanfaatkan potensi lokal kawasan umbul Tlatar (tumbuhan dan lingkungannya) diperlukan dalam pendidikan lingkungan pada materi Struktur Tumbuhan. Potensi lokal umbul Tlatar terdapat lingkungan kawasan wisata yang perlu dijaga kelestariannya dan hasil mapping jenis tumbuhan di kawasan umbul Tlatar yaitu Alfata (Alfafa Tropicana), Cenil/selada air, kayu putih dan lain-lain. Potensi lokal umbul Tlatar memiliki kelebihan dan efektif dalam pembelajaran materi struktur tumbuhan.
Berdasarkan permasalahan yang dikemukakan, perlu adanya penelitian pengembangan modul biologi berbasis discovery learning struktur tumbuhan dengan menggunakan potensi Lokal umbul Tlatar untuk meningkatkan regulasi diri dan sikap kepedulian lingkungan siswa SMA.

\section{Metode}

Penelitian ini merupakan penelitian pengembangan R\&D (Research and Development) merujuk pada model Borg \& Gall (1989) yang dimodifikasi yaitu: 1) analisis kebutuhan, 2) perencanaan, 3) mengembangkan bentuk produk awal / desain produk awal, 4) uji coba kelompok kecil, 5) revisi terhadap produk utama, 6) uji lapangan terbatas, 7) revisi produk, 8) uji lapangan operasional dan 9) revisi produk akhir.

Subjek uji coba penelitian terdiri dari 4 kelompok subjek yang meliputi uji coba awal (validasi ahli materi, ahli perangkat, ahli media dan ahli soal), uji coba kelompok kecil yaitu 2 orang guru praktisi SMA dan 19 orang siswa serta uji coba lapangan operasional dilakukan pada 33 siswa kelas XI IPA.3 SMAN 2 Boyolali Kabupaten Boyolali.

Data analisis kebutuhan diperoleh dari kuesioner dan wawancara terhadap siswa dan guru tentang kondisi pembelajaran di kelas, data ketercapaian 8 SNP (Standar Kompetensi Lulusan, Standar Isi, Standar Proses, Standar Penilaian, Standar Pendidik dan Tenaga Pendidik, Standar Sarana dan Prasarana, Standar Pengelolaan serta Standar Biaya Operasional), data hasil ujian nasional dari Kemendiknas, data hasil ulangan harian, analisis buku ajar bertujuan untuk mengetahui persentase muatan isi (tujuan, materi, kegiatan, dan evaluasi) tentang aspek keterampilan regulasi diri dan aspek sikap kepedulian lingkungan, dan observasi terhadap potensi kawasan umbul Tlatar untuk mengetahui berbagai jenis tumbuhan yang dapat digunakan sebagai sumber belajar pada materi struktur tumbuhan.

Data hasil validasi ahli dan praktisi pendidikan diperoleh melalui angket kelayakan modul. Data hasil uji terbatas berupa data kualitatif yang diperoleh melalui angket kelayakan modul oleh guru dan siswa.

Instrumen pengumpulan data berupa lembar observasi dan angket untuk 
mengetahui keterampilan regulasi diri dan sikap kepedulian lingkungan siswa, wawancara guru dan siswa, angket tanggapan guru dan siswa mengenai bahan ajar, tes untuk mengetahui hasil belajar aspek pengetahuan.

Data yang diperoleh, dilakukan analisis data menggunakan deskriptif kuantitatif untuk menganalisis data hasil validasi guru biologi dan uji kelompok kecil berupa masukan, tanggapan, saran dan kritik perbaikan yang terdapat pada angket. Data nilai penskoran dianalisis secara deskriptif kuantitatif melalui rumus (1).

$$
K=\frac{\sum n i}{N} \times 100 \% \text {. }
$$

\author{
Keterangan : \\ $K \quad$ : persentase skor yang diperoleh \\ $\sum n i$ : jumlah skor yang diperoleh \\ $\mathrm{N}$ : jumlah skor $\max$
}

\section{Hasil dan pembahasan}

Modul berbasis Discovery Learning dengan memanfaatkan potensi lokal umbul Tlatar pada materi struktur tumbuhan dikembangkan dengan merujuk desain pengembangan Borg \& Gall (1989). Tahap studi pendahuluan dilakukan beberapa kegiatan, dapat dilihat pada Tabel 1.

Tabel 1. Hasil studi pendahuluan

\begin{tabular}{|c|c|}
\hline Kegiatan & Hasil \\
\hline $\begin{array}{l}\text { Pemetaan delapan Standar } \\
\text { Nasional Pendidikan }\end{array}$ & $\begin{array}{l}\text { standar } 2 \text { ( standar proses) penyumbang skor gap terbanyak yaitu } \\
2,78 \% \text { dari skor ideal }\end{array}$ \\
\hline $\begin{array}{l}\text { Memberikan angket } \\
\text { kebutuhan kepada guru } \\
\text { terkait bahan ajar di } \\
\text { sekolah }\end{array}$ & $\begin{array}{l}\text { bahan ajar kurang menarik karena gambar tidak jelas , ringkasan } \\
\text { materi kurang, sedikit kegiatan untuk mendukung aktivitas siswa } \\
\text { belajar }\end{array}$ \\
\hline $\begin{array}{l}\text { Wawancara dengan guru } \\
\text { biologi kelas XI terkait } \\
\text { bahan ajar yang } \\
\text { dibutuhkan. }\end{array}$ & $\begin{array}{l}\text { guru menghendaki modul yang menarik, berwarna, gambar jelas, } \\
\text { mudah dipahami ,melatih keterampilan regulasi diri dalam berpikir, } \\
\text { meningkatkan sikap kepedulian lingkungan, mengaitkan pembelajaran } \\
\text { dengan potensi di sekitar sekolah ,melatih siswa mandiri dalam belajar, } \\
\text { dan materi yang lebih lengkap dari bahan ajar /modul yang sudah } \\
\text { sesuai silabus dan visi misi sekolah berarti ada yang dibutuhkan }\end{array}$ \\
\hline $\begin{array}{l}\text { Menyebarkan angket } \\
\text { kebutuhan siswa terkait } \\
\text { dengan bahan ajar di } \\
\text { sekolah }\end{array}$ & $\begin{array}{l}\text { Guru menghendaki modul yang menarik, berwarna, gambar jelas, } \\
\text { mudah dipahami, melatih keterampilan regulasi diri dalam berpikir, } \\
\text { meningkatkan sikap kepedulian lingkungan, mengaitkan pembelajaran } \\
\text { dengan potensi di sekitar sekolah ,melatih siswa mandiri dalam belajar, } \\
\text { dan materi yang lebih lengkap dari bahan ajar /modul yang sudah } \\
\text { sesuai silabus dan visi misi sekolah }\end{array}$ \\
\hline $\begin{array}{l}\text { Menyebarkan angket } \\
\text { kebutuhan siswa terkait } \\
\text { dengan bahan ajar di } \\
\text { sekolah }\end{array}$ & $\begin{array}{l}\text { Berdasarkan analisis angket kebutuhan siswa diperoleh bahwa bahan } \\
\text { ajar yang digunakan tidak menarik karena tidak berwarna, komposisi } \\
\text { materi kurang lengkap sehingga harus mencari dari sumber lain, dan } \\
\text { sulit dipahami }\end{array}$ \\
\hline $\begin{array}{l}\text { Memberikan angket untuk } \\
\text { memperoleh profil } \\
\text { keterampilan regulasi diri } \\
\text { siswa. }\end{array}$ & $\begin{array}{l}\text { Berdasarkan pemberian angket keterampilan regulasi diri diperoleh } \\
\text { rata-rata masih sangat kurang Receiving (50.71), Evaluating (33.43), } \\
\text { Triggering (30.54), Searching (43.37), Formulating (50.60), } \\
\text { Implementing (44.52) dan Assessing }(45,70)\end{array}$ \\
\hline $\begin{array}{l}\text { Memberikan angket untuk } \\
\text { memperoleh profil } \\
\text { kemampuan sikap } \\
\text { kepedulian lingkungan } \\
\text { siswa. }\end{array}$ & $\begin{array}{l}\text { Berdasarkan hasil angket sikap kepedulian keadaan lingkungan masih } \\
\text { kurang (53.29), aspek tidak merusak lingkungan masih sangat kurang } \\
\text { (44.23), aspek menjaga kebersihan masih kurang (43.14), aspek } \\
\text { tanggung jawab terhadap lingkungan masih kurang (51.54), dan aspek } \\
\text { menjaga kenyamanan lingkungan sangat kurang (48.07). }\end{array}$ \\
\hline $\begin{array}{l}\text { Menganalisis potensi } \\
\text { modul untuk meningkatkan } \\
\text { kemampuan regulasi diri } \\
\text { siswa. }\end{array}$ & $\begin{array}{l}\text { bahan ajar } 1 \text { diperoleh hasil pemenuhan hanya pada aspek Receiving } \\
\text { relevant information (menerima informasi yang relevan) } 55 \% \text { dan } \\
\text { aspek Implementing the plan (mengimplementasikan rencana) } 30 \% \text {. } \\
\text { bahan ajar } 2 \text { diperoleh hasil pemenuhan hanya pada aspek Receiving } \\
\text { relevant information (menerima informasi yang relevan) } 55 \% \text {. } \\
\text { bahan ajar } 3 \text { diperoleh hasil pemenuhan hanya pada aspek Receiving } \\
\text { relevant information (menerima informasi yang relevan) } 32,5 \%\end{array}$ \\
\hline $\begin{array}{l}\text { Menganalisis potensi } \\
\text { modul untuk meningkatkan } \\
\text { sikap kepedulian } \\
\text { lingkungan siswa. }\end{array}$ & $\begin{array}{l}\text { bahan ajar 1,2 dan } 3 \text { diperoleh hasil pemenuhan aspek sikap peduli } \\
\text { lingkungan } 0 \% \text {. }\end{array}$ \\
\hline
\end{tabular}


Berdasarkan hasil studi pendahuluan tersebut standar proses perlu ditingkatkan melalui perbaikan proses pembelajaran. Perbaikan proses pembelajaran dilakukan dengan menyediakan bahan ajar yang dibutuhkan siswa dan guru. Bahan ajar yang menarik, gambar jelas berwarna melatih keterampilan regulasi diri dan sikap kepedulian lingkungan.

Tahap perencanaan meliputi kegiatan: 1) Menentukan tujuan pembelajaran modul; 2) Menentukan format aktivitas di dalam modul; 3) Menentukan sub pokok bahasan materi struktur tumbuhan; 4) Menentukan format dan visualisasi isi modul; 5) Menentukan format perangkat pembelajaran untuk implementasi modul; 6) Menentukan prosedur terkait pengembangan modul. Tujuan modul dirumuskan pada kisi-kisi indikator matriks yang dikembangkan berdasarkan aspek keterampilan regulasi diri dan sikap kepedulian lingkungan. Penentuan format yang dipilih untuk aktivitas di dalam modul dirumuskan pada matriks modul berisi kegiatan yang mewakili sintak dari model belajar discovery learning. Materi sesuai Indikator Pencapaian Kompetensi (IPK) dalam bahasan modul terdiri dari jaringan tumbuhan, organ tumbuhan, dan totipotensi dan kultur jaringan. Format isi modul yang dikembangkan merujuk pada format modul terdiri dari: pendahuluan, tujuan pembelajaran, pengalaman belajar, sumber belajar dan tes evaluasi. Rancangan pembelajaran yang disusun berdasarkan kegiatan pada sintak model pembelajaran discovery learning. Pengembangan modul yang direncanakan dalam menentukan subjek penelitian, data dan teknik pengambilannya dimulai dari tahap pengembangan produk, validasi sampai uji coba.

Tahap pengembangan produk awal menghasilkan draf modul yang siap diuji coba atau divalidasi. Pengembangan desain produk awal mencakup kegiatan identifikasi materi pelajaran yang dikembangkan, pengembangan kegiatan modul, pengembangan soal evaluasi, mengumpulkan bahan pendukung seperti materi dan gambar agar didapatkan draf produk yang baik dan berkualitas, draf modul dilengkapi dengan perangkat pembelajaran yang mencakup silabus, RPP, dan instrumen penilaian yang mengaju aspek keterampilan regulasi diri dan sikap kepedulian lingkungan.
Modul berbasis Discovery learning dengan memanfaatkan potensi lokal umbul Tlatar dikembangkan menggunakan sintak model pembelajaran Discovery Learning Brunner (Illahi, 2012) yaitu:1) stimulation (stimulus), 2) problem statement (identifikasi masalah), 3) data collection (pengumpulan data), 4) data processing (proses data), 5) verification (verifikasi), dan 6) generalization (generalisasi).

Produk modul berbasis Discovery Learning dengan memanfaatkan potensi lokal umbul Tlatar memiliki kelebihan dibandingkan dengan modul di sekolah karena isi (tujuan, materi, kegiatan dan soal evaluasi) modul memiliki persentase pemenuhan sintak Discovery Learning dengan memperhatikan aspek regulasi diri dan sikap kepedulian lingkungan yang lebih tinggi.

Tahap uji coba permulaan yang dilakukan berupa validasi ahli. Validasi dilakukan oleh ahli meliputi validasi instrumen pembelajaran dan aspek dalam modul (materi, penyajian, soal/evaluasi, dan perangkat pembelajaran). Hasil uji coba permulaan dapat dilihat pada Tabel 2 .

Tabel 2. Validasi modul dari ahli

\begin{tabular}{lcl}
\hline \multicolumn{1}{c}{ Ahli } & $\begin{array}{c}\text { Persentase } \\
\text { Skor (\%) }\end{array}$ & Kualifikasi \\
\hline Materi & 96.23 & Sangat baik \\
Penyajian & 87.09 & Sangat baik \\
$\begin{array}{l}\text { Perangkat } \\
\text { Pembelajaran }\end{array}$ & 80.5 & Baik \\
$\begin{array}{l}\text { Evaluasi } \\
\text { pembelajaran }\end{array}$ & 93.75 & Sangat baik \\
\hline
\end{tabular}

Berdasarkan hasil validasi diperoleh rata-rata dari seluruh aspek penilaian materi oleh ahli adalah 96,23\% dengan kualifikasi sangat baik, artinya materi di dalam modul siswa telah memenuhi kriteria dan layak untuk dilanjutkan uji lapangan terbatas. Berdasarkan hasil validasi diperoleh rata-rata dari seluruh aspek penyajian modul oleh ahli adalah 87,09\% dengan kualifikasi sangat baik, artinya penyajian produk modul siswa telah memenuhi kriteria dan layak. Berdasarkan hasil validasi diperoleh ratarata dari seluruh aspek penilaian perangkat pembelajaran oleh ahli adalah 80,5\% dengan kualifikasi sangat baik. Berdasarkan hasil validasi diperoleh ratarata dari seluruh aspek evaluasi pembelajaran oleh ahli adalah 93,75\% dengan kualifikasi sangat baik, artinya evaluasi pembelajaran di dalam modul 
guru telah memenuhi kriteria dan layak untuk dilanjutkan uji lapangan terbatas.

Tahap selanjutnya setelah dilakukan uji coba permulaan adalah revisi produk pertama. Pada tahap ini dilakukan perbaikan modul berdasarkan saran dari validator. Modul diperbaiki berdasarkan masukan ahli materi terdiri materi struktur tumbuhan sesuai dengan silabus, stimulus dikuatkan, masukan ahli pengembangan modul terdiri dari cover dibuat menarik dan gambar diperbesar, masukan ahli perangkat pembelajaran terdiri dari memperjelas kegiatan siswa di laboratorium dan skala nilai 100, masukan ahli evaluasi yaitu dibuat kisi-kisi soal sesuai KD dan indikator. Selanjutnya dilakukan uji lapangan terbatas yang melibatkan praktisi pendidikan (guru biologi) dan 19 orang siswa (kelas XI IPA dan XII IPA). Hasil uji coba permulaan disajikan dalam Tabel 3.

Tabel 3. Penilaian modul oleh praktisi dan siswa

\begin{tabular}{lcc}
\hline \multicolumn{1}{c}{ Validasi } & $\begin{array}{c}\text { Persentase } \\
\text { Skor (\%) }\end{array}$ & Kualifikasi \\
\hline $\begin{array}{l}\text { Praktisi } \\
\text { pendidikan }\end{array}$ & 95.83 & Sangat baik \\
Siswa & 85.79 & Sangat baik \\
\hline
\end{tabular}

Tabel 4.Hasil uji nilai keterampilan regulasi diri

\begin{tabular}{|c|c|c|c|c|}
\hline $\begin{array}{c}\text { Data } \\
\text { Hasil } \\
\text { Belajar }\end{array}$ & Kelas & $\begin{array}{c}\text { Uji } \\
\text { Norm } \\
\text { alitas } \\
\text { (Sig) }\end{array}$ & $\begin{array}{c}\text { Uji } \\
\text { Homoge } \\
\text { nitas } \\
\text { (Sig) }\end{array}$ & $\begin{array}{c}\text { Uji U } \\
\text { (Sig) }\end{array}$ \\
\hline \multirow{2}{*}{ Pre-test } & Modul & $\begin{array}{c}0,088 \\
>0,05\end{array}$ & \multirow{2}{*}{ (2) } & \multirow{2}{*}{$\begin{array}{l}0,000 \\
<0,05\end{array}$} \\
\hline & Kontrol & $\begin{array}{r}0,094 \\
>0,05\end{array}$ & & \\
\hline \multirow{2}{*}{ Post-test } & Modul & $\begin{array}{r}0,254 \\
>0,05\end{array}$ & & \multirow{2}{*}{$\begin{array}{l}0,000 \\
<0,05\end{array}$} \\
\hline & & $\begin{array}{r}0,417 \\
>0,05\end{array}$ & & \\
\hline \multirow{2}{*}{$N$-gain } & Modul & $\begin{array}{r}0,157 \\
>0,05\end{array}$ & \multirow{2}{*}{$\begin{array}{c}0,093> \\
0,05\end{array}$} & \multirow{2}{*}{$\begin{array}{l}0,000 \\
<0,05\end{array}$} \\
\hline & Kontrol & $\begin{array}{r}0,000 \\
<0,05 \\
\end{array}$ & & \\
\hline
\end{tabular}

Penilaian modul oleh guru dan siswa modul menunjukkan kualifikasi sangat baik, sehingga dapat dilanjutkan ke tahap uji lapangan operasional/efektivitas setelah memperbaiki kekurangan modul berdasarkan saran yang diperoleh guru berupa pada bagian permasalahan upayakan siswa yang memunculkan permasalahan, penambahan beberapa soal dan materi lebih dilengkapi agar lebih memperkaya modul. Prastowo (2011), bahan ajar harus memuat kompetensi yang dicapai siswa, sehingga efektivitas modul bisa terlihat. Hasil uji coba operasional untuk efektivitas modul terhadap regulasi diri siswa dapat dilihat di Tabel 4.

Tabel 4. menunjukkan data post-test dianalisis dan diperoleh Sig. $(0,000<0,05)$ artinya kedua sampel berbeda signifikan, dengan rata-rata post-test kelas modul yang lebih tinggi berarti modul berbasis Discovery Learning pada materi struktur tumbuhan efektif untuk meningkatkan keterampilan regulasi diri siswa.

Berdasarkan hasil uji menunjukkan bahwa modul berbasis Discovery Learning dengan memanfaatkan potensi lokal umbul Tlatar efektif dalam meningkatkan keterampilan regulasi diri siswa. Peningkatan keterampilan regulasi diri siswa selama pembelajaran menjawab keefektifan modul pembelajaran berbasis Discovery Learning dengan memanfaatkan potensi lokal umbul Tlatar.

Selain keterampilan regulasi diri, aspek lain yang diukur adalah sikap kepedulian lingkungan siswa. Data nilai aspek sikap kepedulian lingkungan. Siswa pada kelas modul dan kelas kontrol disajikan pada Tabel 5 .

Tabel 5. Nilai sikap kepedulian lingkungan

\begin{tabular}{ccc}
\hline $\begin{array}{c}\text { Hasil Belajar } \\
\text { Siswa }\end{array}$ & Kelas & Rata-rata \\
\hline \multirow{2}{*}{ Pre-test } & Modul & 12,12 \\
& Kontrol & 11,06 \\
\hline \multirow{2}{*}{ Post-test } & Modul & 81,97 \\
& Kontrol & 28,82 \\
\hline \multirow{2}{*}{ N-gain } & Modul & 0,80 \\
& Kontrol & 0,21 \\
\hline
\end{tabular}

Berdasarkan Tabel 5. dapat dilihat bahwa rerata sikap kepedulian lingkungan sebelum diberikan pembelajaran pada kedua kelas tidak jauh berbeda (rerata kelas modul 12,12 dan kelas kontrol 11,06). Setelah dilakukan pembelajaran dengan perlakuan yang berbeda yaitu pembelajaran menggunakan modul dan pembelajaran diskusi kelompok, kemudian diberikan post-test pada kedua kelas. Pada kelas modul diperoleh rerata 81,97 dengan kriteria tinggi yang artinya siswa sadar akan sendiri dan bisa melakukan tindakan dengan sikap kepedulian lingkungan dalam proses belajarnya. Sedangkan pada kelas kontrol diketahui rata-rata 28,82 yang termasuk dalam kriteria rendah yaitu bisa menuju kesadaran sikap kepedulian lingkungan sendiri jika didorong dan didukung sarana (modul yang mendukung dalam belajar). 
Nilai pre-test dan post-test tersebut kemudian dihitung tingkat kenaikan sikap kepedulian lingkungannya untuk mengetahui efektivitas pembelajaran dengan modul. Berdasarkan data yang diperoleh selanjutnya dilakukan uji statistik untuk mengetahui keefektifan modul pembelajaran Discovery Learning dengan memanfaatkan potensi lokal umbul Tlatar berperan dalam meningkatkan sikap kepedulian lingkungan. Uji prasyarat dilakukan dengan menghitung normalitas data pre-test, post-test, dan gain, kemudian dilakukan uji lanjut yaitu uji T.

Setelah dilakukan pembelajaran dan post-test, diperoleh hasil rubrik post-test kelas modul dan kontrol sig $(0,000<0,05)$ yang artinya rata-rata post-test kelas modul lebih tinggi dari kelas kontrol. Hal tersebut mengindikasikan bahwa modul berbasis discovery learning dengan memanfaatkan potensi lokal umbul Tlatar lebih efektif meningkatkan sikap kepedulian lingkungan siswa.

Gambaran keterkaitan antara proses pembelajaran dan produk pembelajaran dengan menggunakan modul berbasis Discovery Learning dengan memanfaatkan potensi kawasan umbul Tlatar untuk meningkatkan skill regulasi diri dan sikap kepedulian lingkungan, hubungan proses, produk modul tersebut dapat dilihat pada Gambar 1.

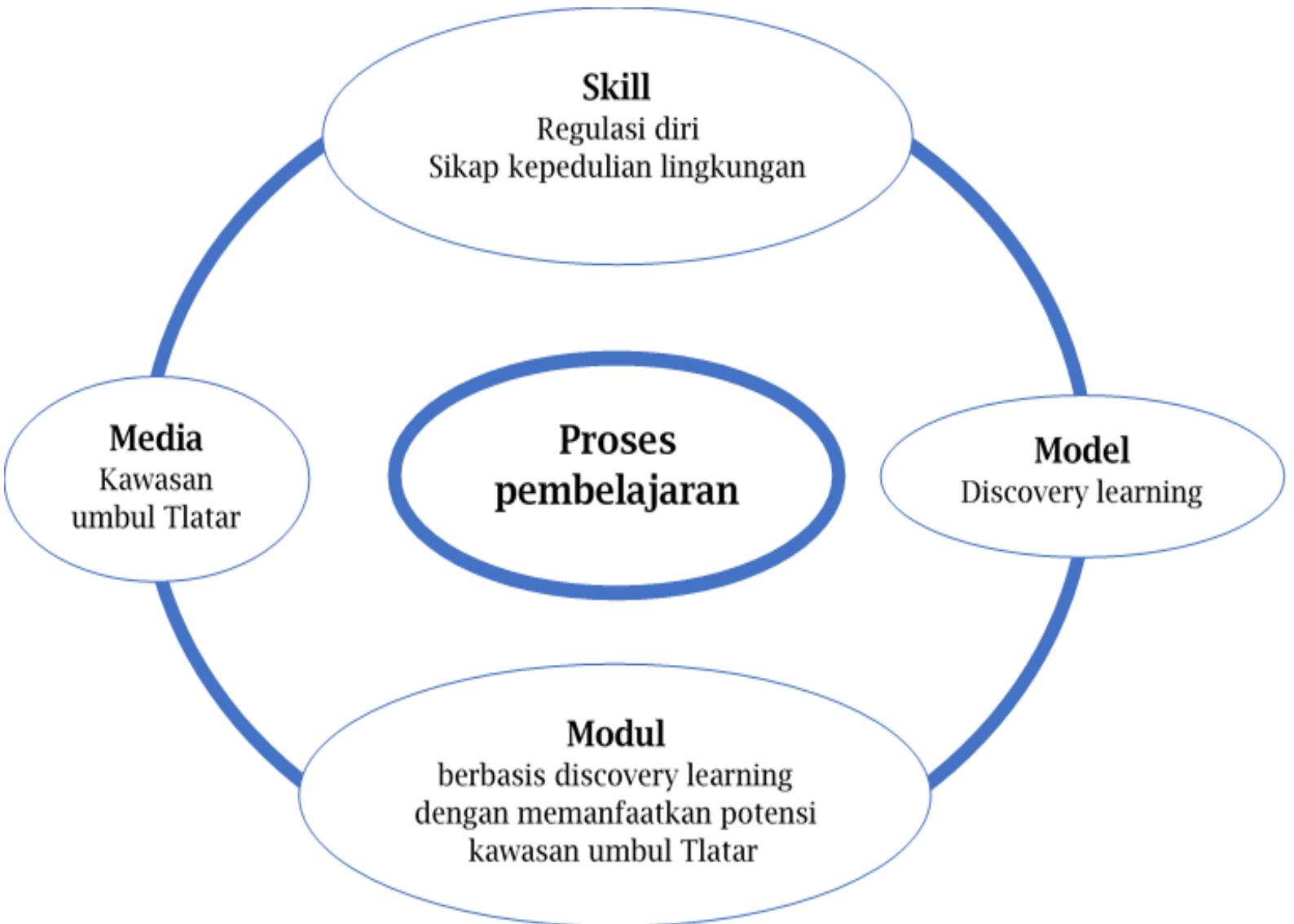

Gambar 1. Keterkaitan antara proses dan produk pembelajaran dengan menggunakan modul berbasis Discovery Learning dengan memanfaatkan potensi kawasan umbul Tlatar

Pada tahap pertama kegiatan modul pembelajaran berbasis Discovery Learning dengan memanfaatkan potensi lokal umbul Tlatar adalah pembentukan kelompok kolaboratif yaitu pembentukan kelompok siswa dengan latar belakang kemampuan akademik yang berbeda yaitu siswa under achievement dan siswa berkemampuan akademik tinggi, dengan tujuan bahwa mereka dapat saling membelajarkan demi tercapainya tujuan. Akanmu \& Fajemidagba
(2013) menyatakan bahwa pembelajaran yang dilakukan bersama-sama akan menunjukkan hasil belajar yang lebih efektif daripada pembelajaran individual. Pendapat tersebut didukung dengan ungkapan Slavin (1995) yang menyatakan bahwa perilaku-perilaku siswa yang muncul dalam kelompok kolaboratif seperti perluasan kognitif, pengajaran oleh teman, permodelan oleh teman, motivasi untuk membantu teman kelompok untuk 
belajar, serta pembenaran dan koreksi untuk teman terbukti meningkatkan hasil belajar siswa berkemampuan akademik atas maupun siswa berkemampuan akademik bawah.

Modul pada materi struktur tumbuhan berbasis Discovery Learning menampilkan prosedur pembelajaran berdasarkan penemuan dengan tahapan sintak terdiri dari Stimulation, Problem statement, Data Collection, Data Processing, Verification dan
Generalization. Menurut Hosman (2014) keunggulan inquiri (Discovery Learning) yaitu menekankan pengembangan pada aspek kognitif, afektif dan psikomotorik secara seimbang, sesuai gaya belajarnya, sesuai perkembangan psikologi belajar modern. Keterlaksanaan sintak Discovery Learning modul dapat dilihat aktivitas siswa dalam pembelajaran, tersaji pada Tabel 6.

Tabel 6. Keterlaksanaan sintak pada aktivitas siswa

\begin{tabular}{|c|c|c|c|c|c|c|}
\hline \multirow[t]{2}{*}{ Tahap pembelajaran } & \multirow[t]{2}{*}{ Indikator aktivitas siswa } & \multicolumn{5}{|c|}{ pertemuan } \\
\hline & & 1 & 2 & 3 & 4 & 5 \\
\hline \multirow{6}{*}{$\begin{array}{l}\text { Pembentukan kelompok } \\
\text { kolaboratif }\end{array}$} & Siswa duduk berkelompok sesuai arahan guru & ya & ya & ya & ya & ya \\
\hline & Siswa memperhatikan aturan rekognisi & ya & ya & ya & ya & ya \\
\hline & $\begin{array}{l}\text { Siswa mengaktifkan pengetahuan lama terkait } \\
\text { dengan bahasan }\end{array}$ & ya & ya & ya & ya & ya \\
\hline & $\begin{array}{l}\text { Siswa memperhatikan regulasi diri ( } 7 \text { aspek) } \\
\text { dalam berpikir }\end{array}$ & ya & ya & ya & ya & ya \\
\hline & $\begin{array}{l}\text { Siswa memperhatikan poin pentingnya sikap } \\
\text { peduli lingkungan ( } 5 \text { aspek) dalam aktivitas }\end{array}$ & ya & ya & ya & ya & ya \\
\hline & Siswa menuju kawasan umbul Tlatar & ya & & ya & & ya \\
\hline $\begin{array}{l}\text { Orientasi } \\
\text { Penyajian } \\
\text { fenomena/stimullation } \\
\text { (mengamati) }\end{array}$ & $\begin{array}{l}\text { Siswa mengamati bagian tumbuhan di kawasan } \\
\text { umbul Tlatar terkait dengan bahasan }\end{array}$ & ya & & ya & & ya \\
\hline $\begin{array}{l}\text { Generalisasi hipotesis } \\
\text { Problem statement } \\
\text { (menanya) }\end{array}$ & Siswa merumuskan masalah & ya & & ya & & ya \\
\hline $\begin{array}{l}\text { Hypotesis testing } \\
\text { Data collection }\end{array}$ & $\begin{array}{l}\text { Siswa mencari jawaban dari rumusan masalah } \\
\text { dari berbagai sumber }\end{array}$ & ya & ya & ya & ya & ya \\
\hline $\begin{array}{l}\text { (mengumpulkan } \\
\text { informasi) }\end{array}$ & Siswa melakukan perencanaan kerja & ya & ya & ya & ya & ya \\
\hline Data processing & $\begin{array}{l}\text { Siswa mengklasifikasi semua informasi dan } \\
\text { hasil pengamatan }\end{array}$ & ya & ya & ya & ya & ya \\
\hline $\begin{array}{l}\text { Membuat kesimpulan } \\
\text { verification }\end{array}$ & $\begin{array}{l}\text { Siswa menyusun kesimpulan dari rumusan } \\
\text { masalah }\end{array}$ & ya & ya & ya & ya & ya \\
\hline $\begin{array}{l}\text { Regulasi } \\
\text { Generalization } \\
\text { (mengkomunikasikan) }\end{array}$ & $\begin{array}{l}\text { Siswa mengkomunikasikan (kelompok } \\
\text { melakukan presentasi hasil diskusi) }\end{array}$ & ya & ya & ya & ya & ya \\
\hline penilaian & $\begin{array}{l}\text { Setiap siswa mengisi rubrik regulasi diri dan } \\
\text { sikap kepedulian lingkungan }\end{array}$ & ya & ya & ya & ya & ya \\
\hline Tes individu & Setiap siswa mengerjakan tes akhir & ya & ya & ya & ya & ya \\
\hline Rekognisi tim & Siswa mendapatkan penghargaan & ya & ya & ya & ya & ya \\
\hline
\end{tabular}

Tampilan produk modul pada salah satu kegiatan belajar mengajar (KBM.1) adalah tampilan utama yang memuat judul dan indikator (materi, aspek regulasi diri dan sikap kepedulian lingkungan) seperti Gambar 2. Sedangkan gambaran keterkaitan antara materi dan istilah tersaji dalam bentuk bagan konsep dan kata kunci (Gambar 3).

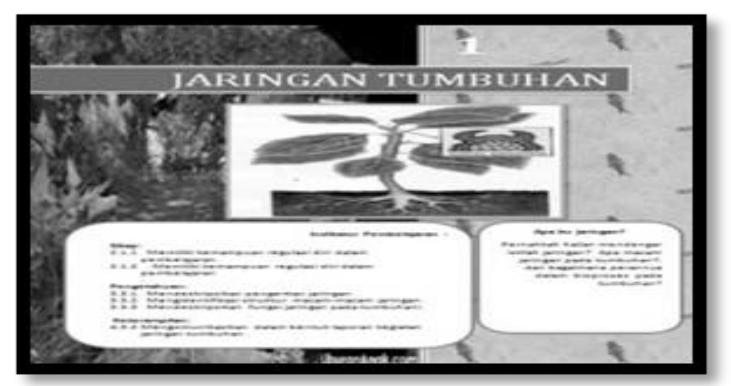

Gambar 2. Tampilan judul dan indikator pembelajaran 


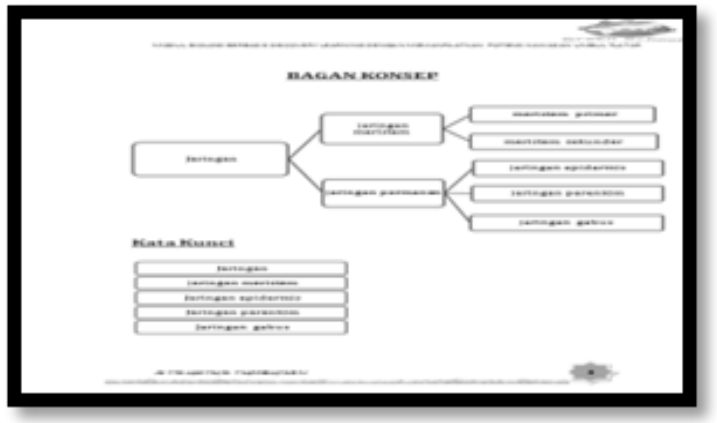

Gambar 3. Bagan konsep dan kata kunci

Siswa membentuk kelompok dan mempelajari aturan yang disajikan untuk melatih kerja kolaborasi yang baik sebelum melakukan kegiatan stimulasi dari discovery learning. Kegiatan stimulasi merupakan kegiatan siswa melakukan pengamatan tumbuhan di kawasan umbul Tlatar, diharapkan melalui pengamatan siswa dapat mengajukan pertanyaanpertanyaan yang menstimulus siswa menuju materi yang akan dipelajari. Penelitian Lavine (2005) menunjukkan bahwa stimulasi sebelum melakukan tahap pengamatan akan membantu siswa membangun konsep dan menghasilkan hasil belajar yang lebih baik. Prayitno (2014), penyajian fenomena yang dikenal dan mendeskripsikan pengetahuannya perlu dilakukan di awal pembelajaran. Stimulus sebelum melakukan pengamatan akan membangun konsep.

Pada tahap problem statement siswa merumuskan masalah dalam bentuk pertanyaan atau hipotesis, dalam prosesnya siswa akan menggunakan keterampilan regulasi diri. Menurut Dumitrașcu (2009) dengan mencoba memecahkan masalah yang diberikan, siswa dapat memperoleh pengalaman untuk membuktikan sesuatu sehingga paham yang dipelajari. Riyanto (2009), siswa aktif membangun sendiri pengetahuannya. Pencarian informasi untuk menjawab rumusan masalah tersebut merupakan tahap data collection.

Pada tahap data processing dilakukan perencanaan percobaan yang berpotensi melatih siswa peduli terhadap keadaan lingkungan, tidak merusak lingkungan, menjaga kebersihan, tanggung jawab terhadap lingkungan dan menjaga kenyamanan lingkungan sekitar kawasan umbul Tlatar. Hal itu bertujuan agar siswa mampu melakukan perencanaan untuk menyelesaikan permasalahan dengan sikap peduli lingkungan. Perencanaan kerja, merumuskan judul dan tujuan kegiatan, siswa dilatih untuk menentukan komponen apa saja yang terlibat dalam percobaan sesuai bahasan (struktur tumbuhan) melalui kegiatan perencanaan. Ketika siswa mampu menuliskan komponen apa saja yang terlibat, artinya siswa telah melatih keterampilan regulasi diri. Pada tahap tersebut siswa terlatih dalam: 1) Receiving relevant information (mencari informasi yang relevan untuk perencanaan kerja), 2) evaluating the information and comparing it to norms (mengevaluasi informasi dan membandingkannya dengan norma sehingga perencanaan yang disusun telah memperhatikan norma/tidak merusak lingkungan), 3) triggering change (memicu perubahan, memicu siswa melakukan perubahan perencanaan yang mengarah pada perbaikan), 4) searching for options (mencari pilihan perencanaan yang tepat), 5) formulating a plan (merumuskan rencana yang akan dilakukan), 6) implementing the plan (mengimplementasikan rencana), 7) assessing the plan's effectiveness (menilai efektivitas rencana yang dilakukan). Selaras dengan hasil penelitian yang dilakukan Ellianawati \& Wahyuni (2016), menjelaskan bahwa manfaat model self regulated (regulasi diri) learning sebagai usaha meningkatkan kemampuan belajar mandiri. Tampilan modul pada tahap data processing seperti Gambar 4.

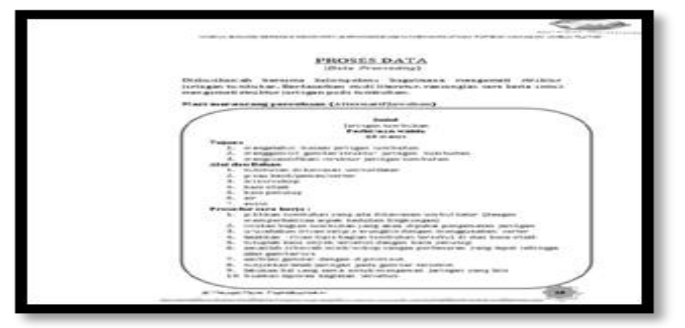

Gambar 4. Tahap data processing

Pada tahap verification akan melatih siswa mencocokkan kesesuaian rumusan masalah dengan tujuan, kemampuan siswa melakukan monitoring sendiri proses belajarnya, sehingga akan mampu merevisi kekurangannya, terlihat pada Gambar 5.

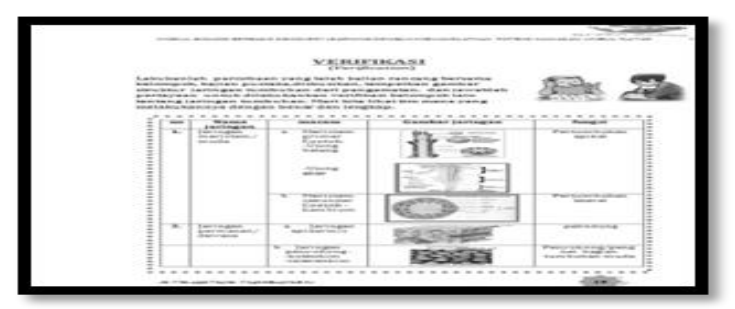

Gambar 5. Tahap verification 
Siswa akan mampu merevisi kekurangannya dalam pembelajarannya. Rivers (2001) berpendapat siswa yang dapat melakukan penilaian terhadap diri sendiri adalah siswa yang sadar akan kemampuannya.

Tahap generalation, siswa dilatih mengkomunikasikan konstruksi sesuatu yang dipelajari. Pembelajaran berbasis discovery learning merupakan jenis pembelajaran konstruktivisme yang dapat mempromosikan kemampuan berpikir (Akçay, 2009). Siswa yang memiliki pemahaman yang baik akan mampu mengkomunikasikan pengetahuan yang telah diperoleh dengan lebih mudah, karena pengetahuan diperoleh dengan konstruksi melalui pengalaman. Selain dilatih mengkomunikasikan, siswa secara berkelompok menyusun laporan dengan tujuan memantau perolehan konsep siswa dalam bentuk tulisan. Modul juga menyajikan bagian yang digunakan untuk menguji pemahaman konsep dalam bentuk soal uraian.

Siswa dapat menambah pengetahuan seputar materi pada bagian wawasan sains yang menyajikan ringkasan materi, alamat website (web bio) yang sebaiknya dikunjungi untuk memperoleh lebih banyak informasi yang bervariasi dan ruang Bioinfo yang berisi tambahan informasi terkait materi.

Modul menyajikan bagian ikhtisar dan refleksi diri yang berisi ringkasan materi dan ruang bagi siswa untuk merenungkan kembali dan mengevaluasi diri tentang materi yang telah dipelajari seperti pada Gambar 6. Modul dapat digunakan untuk menguji pemahaman konsep berdasarkan indikator pencapaian dalam bentuk soal pilihan ganda dan uraian yang tersaji pada bagian evaluasi.

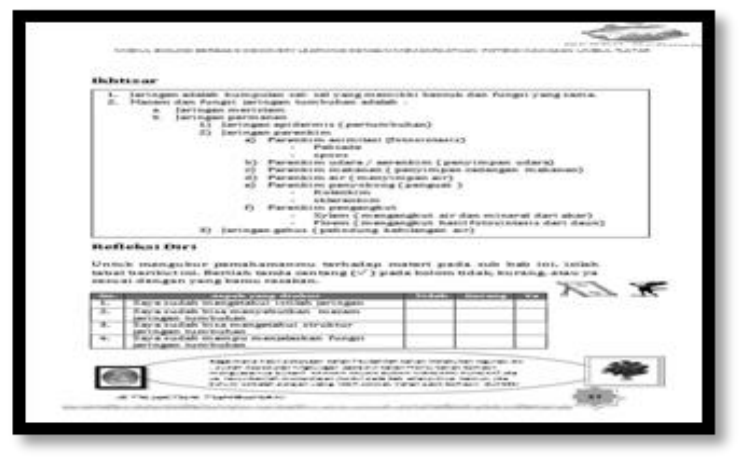

Gambar 6. Ikhtisar dan refleksi diri dalam modul
Pembelajaran dengan menggunakan modul berbasis discovery learning pada materi Struktur Tumbuhan terbukti keberhasilannya, disajikan pada Tabel 7.

Tabel 7. Nilai pada materi struktur tumbuhan

\begin{tabular}{ccc}
\hline Hasil Belajar & Kelas & Rata-rata \\
\hline Siswa & Modul & 08,54 \\
Pre-test & Kontrol & 07,36 \\
& Modul & 79,70 \\
Post-test & Kontrol & 65,11 \\
& Modul & 0,78 \\
N-gain & Kontrol & 0,62 \\
\hline
\end{tabular}

Berdasarkan Tabel 7. dapat dilihat bahwa rerata nilai materi struktur tumbuhan sebelum diberikan pembelajaran pada kedua kelas tidak jauh berbeda (rerata kelas modul 08,54 dan kelas kontrol 07,36). Setelah dilakukan pembelajaran dengan perlakuan yang berbeda yaitu pembelajaran menggunakan modul berbasis discovery learning dan pembelajaran diskusi kelompok/modul biasa, kemudian diberikan post-test pada kedua kelas. Pada kelas modul berbasis discovery learning diperoleh rerata 78,70 dengan kriteria tinggi yang artinya siswa mampu berpikir seperti yang dilatihkan dalam modul berbasis discovery learning dalam belajarnya. Sedangkan pada kelas kontrol diketahui rata-rata 65,11 yang termasuk dalam kriteria sedang, kemampuan berpikir perlu didorong dan didukung sarana (modul yang mendukung dalam belajar).

Nilai pre-test dan post-test tersebut dihitung tingkat kenaikan hasil belajarnya untuk mengetahui efektivitas pembelajaran dengan modul. Rumus yang digunakan adalah rumus gain ternormalisasi. Berdasarkan hasil perhitungan gain ternormalisasi diperoleh rata-rata kenaikan hasil belajar kelas modul dari 33 orang siswa adalah 0,78. Menurut kriteria Hake (1999) nilai tersebut menunjukkan bahwa kenaikan hasil belajar siswa dalam kategori tinggi, sedangkan pada kelas kontrol diketahui data gain sebesar 0,62 dengan kriteria peningkatan sedang.

Berdasar hasil tersebut, modul biologi berbasis discovery learning dapat meningkatkan hasil belajar pada materi struktur tumbuhan yang didukung dengan meningkatnya regulasi diri dan sikap kepedulian lingkungan. 


\section{Simpulan}

Kesimpulan hasil penelitian ini adalah modul berbasis discovery learning dengan memanfaatkan potensi lokal umbul Tlatar telah dikembangkan sesuai sintak discovery learning dan layak untuk digunakan dalam pembelajaran. Modul efektif dalam meningkatkan regulasi diri dan sikap kepedulian lingkungan siswa SMA.

\section{Referensi}

Akanmu, M. A., \& Fajemidagba, M. O. (2013). Guided-discovery learning strategy and senior school students performance in mathematics in Ejigbo, Nigeria. Journal of Education and Practice, 4(12), 82-89. Diambil dari https://iiste.org/Journals/ index.php/JEP/article/view/6515/6 484

Akçay, B. (2009). Problem based learning in science education. Journal of Turkish science education, 6(1), 2636. Diambil dari http://pegem.net/ dosyalar/dokuman/48116-2009042 9114931-04problem-based-learning -in-science-education.pdf

Amini, R., \& Munandar, A. (2010). Pengaruh model pembelajaran pendidikan lingkungann berbasis outdoor terhadap penguasaan konsep pendidikan lingkungan bagi calon guru sekolah dasar. Jurnal Penelitian Pendidikan, 11(1), 14-21. Diambil dari http://jurnal.upi.edu/ file/3_risda.pdf

Borg, W. R., \& Gall, M. (1989). Education research: An introduction (4 ed.). New York: Longman publisher.

Dumitrașcu, D. (2009). Integration of guided discovery in the teaching of real analysis. PRIMUS (Problems, Resources, and Issues in Mathematics Undergraduate Studies), 19(4), 370-380. https://doi.org/10.1080/10511970 802072368

Ellianawati, E., \& Wahyuni, S. (2016). Pemanfaatan self regulated learning sebagai upaya peningkatan kemampuan belajar mandiri pada mata kuliah optik. Jurnal Pendidikan Fisika Indonesia, 6(1), 35-39. Diambil dari https://journal.
unnes.ac.id/nju/index.php/JPFI/arti cle/view/7329

Hake, R. R. (1999). Analyzing change/gain scores.

Hosman, M. (2014). Pendekatan saintifik dan kontekstual dalam pembelajaran abad 21: Kunci sukses implementasi kurikulum 2013. Jakarta: Ghalia Indonesia.

Illahi, M. T. (2012). Pembelajaran discovery strategy \&amp; mental vocational skill. Yogyakarta: Pustaka pelajar.

Lavine, R. A. (2005). Guided discovery learning with videotaped case presentation in neurobiology. Medical Science Educator, 15(1). Diambil dari http://www.iamse.org/ mse-article/guided-discovery-learn ing-with-videotaped-case-present ation-in-neurobiology/

Prastowo, A. (2011). Panduan kreatif membuat bahan ajar inovatif. Yogyakarta: DIVA Press.

Prayitno, B. A. (2014). Potensi sintak model pembelajaran kontruktivisme metakognitif dalam melatihkan berpikir dan kemandirian belajar siswa. Surakarta: Universitas Sebelas Maret.

Rivers, W. P. (2001). Autonomy at all costs: An ethnography of metacognitive self-assessment and self-management among experienced language learners. The Modern Language Journal, 85(2), 279-290. https://doi.org/10.1111/ 0026-7902.00109

Riyanto, H. Y. (2009). Paradigma baru pembelajaran sebagai referensi bagi guru/pendidik dalam implementasi pembelajaran yang efektif dan berkualitas. Jakarta: Kencana Prenada Media Group.

Sari, R. T. (2014). Pengembangan perangkat pembelajaran berorientasi pendidikan karakter dalam pembelajaran IPA SMK. Jurnal Penelitian dan Kajian Ilmiah Menara Ilmu, 3(46).

Slavin, R. E. (1995). Cooperative learning: Theory, research, and practice. Michigan: Allyn and Bacon.

Taylor, S. E., Peplau, L. A., \& Sears, D. O. (2006). Social psychology. New Jersey: Pearson/Prentice Hall. 
Wenning-Vieyra, R. E. (2008). Guidelines and methods for high school teachers for encouraging women in careers in science, technology, engineering, and mathematics.
Journal of Physics Teacher Education Online, 4(4), 7-12. Diambil dari http://www2.phy.ilstu. edu/ wenning/jpteo/issues/jpteo4( 4)spr08.pdf 